\title{
Euskarazko zinema kritikaren bilakaera, gakoak eta erronkak euskal prentsan
}

\author{
Evolución, características y retos \\ de la crítica cinematográfica en euskera
}

\section{Evolution, characteristics and challenges of film criticism in Basque}

\section{Iñaki Lazkano Arrillaga ${ }^{1}$ Simón Peña Fernández ${ }^{2}$}

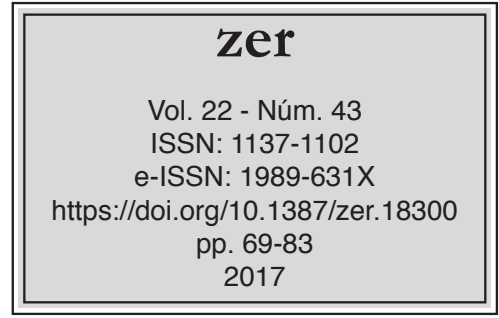

Recibido el 15 de febrero de 2017, aceptado el 29 de junio de 2017.

\begin{abstract}
Laburpena
Zinema kritikak euskal prentsan bizi izan duen bilakaera du ardatz azterlan honek. Euskaldunon Egunkaria kazetako Andres Gostin eta Berria egunkariko Gontzal Agote zinema kritikarien iritzi testuak ez ezik, Koldo Mitxelenak Egan aldizkarian -euskarazko zinema kritika maiztasun jakin batekin eskaini zuen estreinako agerkaria- idatzitakoak ere dira ikergai. Hala, sasoi ezberdinetako zinema kritikarien idatzietan gidoia, eszenaratzea, erritmo narratiboa zein interpretazioaren eremuak nola lantzen diren aztertzeaz gain, egile bakoitzaren gogoetak eta kultur aipamenak ere islatzen dira. Alta, artikuluaren asmoa harago doa. Euskal zinema kritikaren bilakaeraren panoramika doi bat eman ostean, bere gako esanguratsuenak biluzi eta etorkizuneko erronka nagusiak ere identifikatzea baitu xede.
\end{abstract}

Gako-hitzak: Euskara, zinema, kritika, prentsa.

\section{Resumen}

La evolución y renovación que ha experimentado la crítica cinematográfica en la prensa en euskera en los últimos años constituye el principal eje de este trabajo. Además de las críticas cinematográficas firmadas por Andrés Gostin en Euskaldunon Egunkaria y Gontzal Agote en Berria, se han analizado también las escritas por Koldo Mitxelena en la revista Egan. En este análisis no solo se refleja cómo se cultivan las áreas del guion, la puesta en escena,

\footnotetext{
I Universidad del País Vasco/Euskal Herriko Unibertsitatea, inaki.lazkano@ehu.eus

2 Universidad del País Vasco/Euskal Herriko Unibertsitatea, simon.pena@ehu.eus
} 
el ritmo narrativo y la interpretación en las críticas objeto de estudio, sino que también se examinan las reflexiones y referencias culturales aportadas. Tras esta panorámica precisa de la evolución de la crítica cinematográfica en euskera, se tratará de revelar sus claves más significativas e identificar sus principales retos futuros.

Palabras clave: Euskera, cine, crítica, prensa.

\begin{abstract}
The objective of this research work is to analyze the evolution and renewal of film reviews in the Basque press in recent years. In addition to the texts elaborated Andrés Gostin in Euskaldunon Egunkaria and Gontzal Agote in Berria, those written by Koldo Mitxelena in the magazine Egan have also been analyzed. This analysis not only reflects how the script, the staging, the narrative rhythm and the interpretation are analyzed, but also the reflections and cultural references provided. In addition to describing the evolution of film reviews in Basque, this article lists its most significant features and identifies its main future challenges.

Keywords: Basque, cinema, criticism, press.
\end{abstract}




\section{Sarrera}

Euskarazko prentsan argitaratutako zinema kritikaren gakoak eta bilakaera ezagutzea da artikulu honen funtsa. Izan ere, akademikoki landu gabeko esparrua da, kasik. Berez, 1990ean, Euskaldunon Egunkaria kazetaren sorrerarekin batera, bereganatu zuen prentsan bere lekua euskarazko zinema kritikak. Dena dela, aurrekariak -aldizkarien ekarpena, bereziki- aintzat hartzea ezinbestekoa da iritzi genero mota honen bilakaera egokiro azaltzeko. Horrexegatik, artikulu honetan, Koldo Mitxelena bide-urratzaileak Egan aldizkarian idatzitako zinema kritikak ere -euskal zinema kritika berriaren abiapuntu direnak- aztertuko dira.

Hala, euskarazko zinema kritikaren ezaugarriak zeintzuk diren zehazteko asmoz, garai ezberdinetako hiru zinema kritikariren irizpideak hartuko dira oinarri. Eta, irizpide horiek identifikatzeko, aipatu kritikariek euren eginkizunean analisi-kategoriak nola darabiltzaten ikertuko da. Alegia, gidoia, eszenaratzea, erritmo narratiboa zein interpretazioaren azterketaren bitartez zinema kritikari bakoitzaren paradigma kritikoa argitzeko asmoa dago. Izan ere, paradigma kritiko bakarra ez dago. Arrazoi horregatik berebiziko garrantzia erdiesten du euskarazko zinema kritikaren bilakaera aztertzeak.

Asetu nahi diren ikerketa-galdera esanguratsuenek euskarazko prentsan argitaratutako zinema kritikaren egitura, estiloa eta ezaugarri nagusiak nahiz bilakaera ere argitzea xede duten arren, saihetsezina zaigu euskarazko zinema kritikak testuinguru digital berrian bizi duen egoerari buruz ere gogoeta egitea. Idazki honetan, hain justu, euskarazko prentsaren zinema kritikaren gakoak biluzi eta bere bilakaera azaldu ostean, egungo egoeraren gordina eta etorkizuneko erronkak izango dira hizpide.

\section{Metodologia eta lagina}

Euskal prentsan argitaratutako zinema kritikaren izaera, ezaugarriak zein bilakaera ere ikertzeko metodologia egoki bat aukeratzea ezinbestekoa da. Kasu honetan, hain zuzen, azterketa kualitatibo baten aldeko hautua egin da. Hala, zinema kritikak oinarri harturik, filmen kalitatea epaitzeko kritikari bakoitzak erabilitako irizpideak zehaztuko dira. Horretarako, neurri handi batean, Jose Antonio Planes Pedreñok (2014: 28-31) El paradigma estético en la crítica cinematográfica de Ángel FernándezSantos doktorego tesian darabilen metodologia izango da eredu.

Gauzak horrela, zinema hizkuntzaren espresio-konplexutasuna ahalik eta argien aztertze aldera, bere funtsezko osagaien funtzionamendua kategoria edo maila ezberdinetan disekzionatuko da: egitura, gidoia, eszenaratzea, erritmo narratiboa, interpretazioa eta erreferentziak, hurrenez hurren. Planes Pedreñok ere kategoria "generikoak" -drama, komedia, beldurra...- aztertu izan ditu. Azken hauek, ostera, ikerketa honetatik at uztea erabaki da. Zinema kritikariaren irizpideei buruz ezer gutxi dakartelako, batik bat. Are gutxiago, genero hibridazioa nagusi den testuinguru batean.

Hortaz, ikerketa honetan aukeratutako zinema kritikarien testuetan aipatu maila edo kategoria horiek guztiak aztertuko dira. Lehenik eta behin, zinema kritikaren testuaren egiturari erreparatuko zaio. Bereziki, testuek titulua eta fitxa teknikoa daramatzaten ala ez behatuko da. Jarraian, Planes Pedreñok proposatutako kategoriak zinema kritikari bakoitzaren testuetan nola islatzen diren izango da aztergai. Hala, 
gidoiaren eremuan, argudioaz landa, gidoiaren beraren egitura eta kohesioa, ikuspuntua, pertsonaien eraikuntza eta irudimena ere hartuko dira kontuan. Eszenaratzeari dagokionez, interpretazio zabal baten aldeko hautua egin da eta, dekoratuak, argiztapena, jantziak, makillajea eta beste ohiko elementuak aztertzeaz gain, irudiaren dimentsiokoak ere (kamera mugimenduak, enkuadrea, enfokea...) zelan jasoak dauden ikertuko da.

Taula 1. Analisiaren kategoriak.

\begin{tabular}{|c|c|c|c|c|c|}
\hline $\begin{array}{l}\text { Testuaren } \\
\text { egitura }\end{array}$ & Gidoia & Eszenaratzea & Interpretazioa & $\begin{array}{l}\text { Erritmo } \\
\text { narratiboa }\end{array}$ & Erreferentziak \\
\hline \begin{tabular}{|l|} 
Bateratua \\
Banatua \\
(fitxa teknikoa, \\
titulua)
\end{tabular} & $\begin{array}{l}\text { Argudioa } \\
\text { Egitura } \\
\text { Kohesioa } \\
\text { Irudimena } \\
\text { Ikuspuntua } \\
\text { Pertsonaiak }\end{array}$ & $\begin{array}{l}\text { Planoak } \\
\text { Kamera } \\
\text { mugimenduak } \\
\text { Argiztapena } \\
\text { Jantziak } \\
\text { Dekoratuak }\end{array}$ & $\begin{array}{l}\text { Protagonistak eta } \\
\text { bigarren mailako } \\
\text { aktoreak } \\
\text { (aurpegia, gorputza, } \\
\text { ahotsa, mugimendua) } \\
\text { Erregistro } \\
\text { ezberdinetara } \\
\text { egokitzeko gaitasuna } \\
\text { Hoztasunaren eta } \\
\text { histrionismoaren } \\
\text { errefusatzea }\end{array}$ & $\begin{array}{l}\text { Konposizioa } \\
\text { Muntaia } \\
\text { Jarraitutasun } \\
\text { narratiboa } \\
\begin{array}{l}\text { Erretorikaren } \\
\text { kritika }\end{array}\end{array}$ & $\begin{array}{l}\begin{array}{l}\text { Estilo filmikoak } \\
\text { (egileak } \\
\text { eta korronteak) }\end{array} \\
\text { Aurrekariak } \\
\text { (pelikulak, } \\
\text { liburuak, komikiak) }\end{array}$ \\
\hline
\end{tabular}

Iturria: Egileek beraiek egina.

Interpretazioaren kategorian, aldiz, aktoreen lanari buruzko iruzkinak izango dira ardatz. Aktorearen keinuak, mugimenduak eta ahotsa erabiltzeko modua, batik bat. Eta, noski, aktoreak berak pertsonaia bakoitzaren ezaugarrietara egokitzeko agertzen duen trebezia. Erritmo narratiboan, ostera, kritikariek konposizioari eta muntaiari eskaintzen dioten garrantzia aintzat hartuko da. Eta, halaber, jarraitutasun narratiborik ez denetan, kritikariek beraiek darabiltzaten argudioak bilduko dira. Azkenik, erreferentzien atalean, korronte edo zuzendari jakinen estilo filmikoei buruzko aipuak ez ezik, kritikari bakoitzak aipagai dituen bestelako erreferentziak ere (literatura, historia, antropologia...) kontuan hartuko dira. Finean, zinema kritikari bakoitzak analizatutako pelikulak euren aurrekariekin nola alderatzen edo erkatzen dituen aztertuko da.

Halaber, euskal prentsan argitaratutako zinema kritika ororen analisia egitea ezinezkoa denez gero, euskarazko zinema kritikaren ezaugarri nagusiak islatuko lituzkeen lagin adierazgarri bat aztertzea deliberatu da. Beraz, lehenik eta behin, ikergai diren euskarazko zinema kritiken egileak -Koldo Mitxelena (Egan), Andres Gostin (Euskaldunon Egunkaria) eta Gontzal Agote (Berria) - aukeratu dira. Aukera ez da, inondik inora ere ez, apetatsua. Zinema kritikarien sona ez ezik, euren uzta kritikoaren bolumena ere kontuan hartu baita. Mitxelenak ez zituen bere kritikak eguneroko prentsan argitaratu, Egan aldizkarian baizik. Nolanahi ere, euskarazko zinema kritikaren aitzindari den aldetik, nahitaezkoa iruditu zaigu haren testuak aztertzea.

Behin zinema kritikariak aukeratuta, lagina zehaztea dagokigu. Hiru zinema kritikariak garai ezberdinetakoak izanik, ezinezkoa da ikerketarako denbora-tarte berbera hartzea. Hortaz, Gostinen eta Agoteren kasuan, kritikari gisa aritutako azken 
urtea -urte osoa- aintzat hartuko da, urte horietan jada euren paradigma kritikoa finkatuta zegoela arrazoiturik. Horrenbestez, alde batetik, Gostinek 1997. urtean Euskaldunon Egunkaria kazetan argitaratutako zinema kritikak -65 ale- aztertuko dira. Eta, bestetik, Agotek 2016an Berria kazetan argitara emandakoak -37 ale-. Ordea, bere jardun kritikoa ematen deneko testuinguru berezia kontuan harturik, ezin zaio Koldo Mitxelenari logika berbera ezarri. Beraz, ahalik eta ikuspegirik osatuena eskaintzeko asmoz, Egan aldizkarian kaleratutako kritika guztiak -52 ale- aztertuko dira bere kasuan.

Taula 2. Kritikariak, lagina eta kritika kopurua.

\begin{tabular}{|l|c|c|c|}
\hline Zinema kritikaria & Koldo Mitxelena & Andres Gostin & Gontzal Agote \\
\hline Lagina & $1954-1961$ & 1997 & 2016 \\
\hline Kritika kopurua & 52 & 65 & 37 \\
\hline
\end{tabular}

Iturria: Egileek beraiek egina.

Beraz, arestian azaldutakoa oinarri harturik, ikerketaren unibertsoa 1954tik 2016ra -azken urte hau barne-zabaltzen da. Eta, orotara, 154 zinema kritika aztertuko dira.

\section{Kazetaritzako zinema kritika, gutxietsia bezain ezinbestekoa}

Kritikari guztiak erailak izan behar direla zioen Man Ray artistak. Metafora dadaista horren espiritua, egia esan, oso erroturik dago artea bizibide duten sortzaile guztien artean kasik. Agerikoa baita arte kritikariaren zereginak -zinema kritikariarenak, bereziki- artisten artean erdeinua baino ez duela jaso betidanik.

Zinema kritikak nozitu ohi duen mespretxua ez da artisten eremura mugatzen soil-soilik, baina. Akademia-esparruan ere badu bere isla. Hala, besteak beste, subjektibotasuna, ahultasun metodologikoa nahiz balorazio irizpide inpresionista izatea ere egozten zaizkio. Ildo beretik, Imanol Zumalderen (2011: 20) aburuz, zinema kritikaren alderantzikatze perfektua litzateke film-analisia, doitasun metodologiko zein enpirikoa ditu-eta ezaugarri.

Alta, zinema kritikak film-analisiaren zilegitasun epistemologikorik ez duen arren, ikerketa akademiko gehienak bat datoz bere balioa nabarmentzean. Jacques Aumont eta Michel Marie-k (1990: 20), hain justu, kritika jarduerak hiru eginkizun betetzen dituela diote: informatzea, balioztatzea eta sustatzea. Informazioa eta sustatzea zinema kritikaren jarduerari datxekie. Eta, ebaluazioa, beste iritzi genero orotan legez, ezinbestekoa da. Finean, film baten balio estetikoari buruzko epai argudiatu bat eskaintzea baita zinema kritikariaren xede nagusia.

Informatzea, balioztatzea eta sustatzea dira funtzio kritikoaren hiru zutabe nagusiak, hain zuzen ere. Orobat, zinema kritikaren zeregin pedagogikoa kontuan hartzea ere komeni da. Aumont eta Mariek (1990: 201-21) adierazten duten bezala, kritikari ona, plazer estetikoaren pedagogoa den aldetik, artelanaren oparotasuna ahalik eta irakurle gehienekin partekatzen saiatzen da.

David Bordwell-ek (1995: 38) proposatutako tipologia aintzat hartuz gero, hiru eredutan banatuko litzateke zinema kritika: kazetaritza kritika, saiakera kritikoa eta kritika akademikoa. Kazetaritza kritika egunkarietan zein aldizkarietan egiten da; 
saiakera kritikoa, aldizkari berezituetan; eta, kritika akademikoa -film-analisia gisa ere har daitekeena-, azkenik, unibertsitate mailako argitalpen akademikoetan.

Bordwellen (1995: 40) ikerketa xede nagusietatik urrun -ikerlari estatubatuarrak zinema interpretazioaren inguruko gogoeta oparoan kazetaritzarekin lotutako kritika saihesten du exegesiaren aurrean duen tolerantziarik eza dela eta-, gure azterlanak kazetaritzako zinema kritika hartuko du oinarri. Euskal Herriko prentsan euskaraz argitaratutako zinema kritika, zehazki. Akademikoki ia esploratu gabeko alorra da berau, garatzen deneko testuinguru soziopolitikoarengatik erabat baldintzatua.

Izan ere, euskarazko zinema kritika maiztasun jakin batekin eskaini zuen estreinako agerkaria ez zen kazeta bat izan -36ko gerratean itxi zuten Eguna eta ez zen euskaraz beste kazetarik argitaratu 1990ean Euskaldunon Egunkaria sortu zen arte-, aldizkari bat baizik. Egan aldizkaria, Euskalerriaren Adiskideen Elkartearen gerizpean zinema kritika jorratu zuen 50eko hamarraldiko erdialdetik 60ko hamarraldiko hasiera bitartean, hain justu, euskarazko zinema kritikaren bilakaera eta berritzeari buruzko gogoetaren abiapuntua izango da. Ondoren, Euskaldunon Egunkaria eta Berria kazetetako zinema kritikak analizatuko dira.

\section{Euskarazko zinema kritika: hiru sasoi, hiru eredu}

\subsection{Mitxelena, euskarazko zinema kritikaren bide-urratzaile}

Egan aldizkarian argitaratutako euskarazko zinema kritika askok Koldo Mitxelenaren sinadura dute. Hizkuntzalari entzutetsuak, zinemazale porrokatua bera, zinema kritikari lana partekatu zuen aipatu agerkarian Gurutz Ansola eta Antonio Arruerekin.

Mitxelenak (2006: 14) zineman aditu ez zela aitortu ohi zuen arren -izaera teknikoko kontuetan, batik bat-, gaiaren inguruan ezagutza handia zuenik ezin uka. Gainera, preso izan zen sasoian Ricardo Muñoz Suay-rekin mantendu zuen adiskidetasunezko harremanak, zinemazaletasuna elikatzeaz gainera, bere zinema ikusmoldea ere ikaragarri aberastu zuen. Bere zinema kritikek, zalantzarik gabe, aparteko balioa dute. Mitxelena ez da pelikulen kalitatea epaitzera mugatzen. Horrezaz gain, iruzkintzen dituen filmek iradokitzen dizkioten gaiei buruz gogoeta egiten du sarriaskotan. Alegia, bere kutsu intelektualaz zipriztintzen ditu zinema kritikak.

Zentzu horretan, nolabaiteko paralelismorik bada Mitxelena eta Julian Marias-en zinema kritiken artean. Alfonso Basallo-ren (2016: 134) iritziz, valladolidtar filosofoaren kritika gehienetan analizatutako filmek iradokitutako erreferentzia antropologiko, soziologiko eta kulturalak aurki daitezke. Mitxelenaren kasuan, literatur aipamenak dira nagusi. Unibertsalak (Shakespeare, Gorki, Baudelaire, Cervantes, Joyce) nahiz bertakoak (Mirande, Xenpelar, Lizardi, Orixe).

Halaber, Mitxelenaren zinema kritikek izaera antropologikodun hausnarketa sakonak dakartzate maiz. Det sjunde inseglet (1957) filmak -Ingmar Bergman-en maisulanik esanguratsuena-, kasu, heriotzaz eta Jainkoaren existentziaz ere gogoeta egiteko aukera eskaintzen dio. Mitxelenak, gogoeta horietan murgildurik, Pascal du hizpide eta ondorioztatzen du Ipar Europatik oldarka datorren alaraua ez dela sinestunaren oihua, fede gosearen oihua baizik. Baina Jose Ortega y Gasset-en -Julian Marias-en maisu handia- doktrina filosofikoak ere ez zaizkio arrotz. Are gehiago, 
Akira Kurosawaren Rashomon (1950) filma espainiar filosofoaren perspektibismoaren teoriaren frogapen ederra dela iritzi dio.

Mariasek bezalaxe, zinema darabil Mitxelenak bere kritiketan giza bizitza analizatu eta hari buruz hausnartzeko erreminta gisa. Euskal hizkuntzalariaren jarduera kritikoa, ostera, ez da alde antropologikoan ahitzen inolaz ere. Bere iruzkinek, saiakera izaera nabaria duten arren, beren funtzio kritikoarekin bete-betean konplitzen baitute. Zinema gustuko duten irakurleei informazioa, ebaluazioa eta orientazioa eskaintzen dizkieten testuak dira eta. Gainera, filmak aukeratzeko tenorean, Anjel Lertxundik (1987: 98) nabarmentzen duen bezalaxe, eklektikoa da oso Mitxelena. Joera errealisten maitale izanik ere, joeren atzetik kalitatea antzematen eta dastatzen baitaki.

Mitxelenaren kritikari jarduera ematen deneko testuinguru politikoak -diktadura frankistak-, baina, bere zinema aukera baldintzatzen du erabat. Joxean Fernandezen (2013: 691) aburuz, hainbat faktoreren emaitza da euskaltzainaren hautua. Dena dela, kritikariaren beraren borondateak zeresan handia badu ere, garai hartako zinema areto donostiarren eskaintza eskasaren eragina ezinbestekoa da Mitxelenaren film aukeraketaren urria ulertzeko. Ildo beretik, kontuan hartzeko moduko datu bat dakarkigu Fernandezek: Mitxelenak Egan aldizkarian epaitu zituen filmen \%50 estatubatuarrak ziren.

Zinema ekoizpen estatubatuarretik harago, oso leku gutxi geratzen da beste zinematografientzat. Hala, esate baterako, Ameriketako gainerako herrialdeen presentzia oso txikia da eta altzairuzko oihalaren bestaldeko zinemaren arrastorik ere ez dago. Nolanahi ere, Mitxelenak zinema kritikak egiteko aukeratutako pelikulen artean, $L a$ Strada (Federico Fellini, 1954), Rashomon (Akira Kurosawa, 1950) eta Mon oncle (Jacques Tati, 1958) filmen mailako maisulanak aurki daitezke.

Mitxelenaren zinema kritikak arretaz eta xehe-xehe aztertuz gero, euren berezitasun estrukturala da deigarriena. Hots, euren egitura bateratua. Egileak, fitxa teknikoari muzin egiteaz gain, ez dio sekula zinema kritikari titulurik jartzen. Zinema kritika batek fitxa teknikorik ez izatea hain ezohikoa ez den arren, harrigarria da oso izenburuaren falta. Izan ere, eskuarki, filmaren gai nagusia laburbiltzeko edo zinema kritikariaren azken balorazioa islatzeko erabili ohi da. Mitxelenak, bere aldetik, gogoetagai dituen filmen izenburuak darabiltza idazpuruak ipintzeko.

Hizkuntzalariaren testu bakarreko zinema kritika horretan, aipatu gogoeta antropologikoaz landa, informazioa da nagusi. Funtsean, pelikularen argumentuaren nondik norakoak eskaintzen dira. Hala eta guztiz ere, informazioa ez da beti jarraibide berberen arabera moldatzen. Gehienetan, irakurlea kokatze aldera, argumentuaren sintesi edo laburpen bat dakar Mitxelenak. Beste batzuetan, berriz, gaiari zuzenzuzenean heltzen dio eta ez du argumentua laburtzen. Batera zein bestera egiten du. Edonola ere, ohikoagoa da azken aukera hau. Bereziki, atsegin ez dituen filmen kritiketan. The Robe (Henry Koster, 1953) eta Betrayed (Gottfried Reinhardt, 1954) pelikulen kritikak dira horren erakusle. Azken zinema kritiketan -1961ean argitaratutakoak-, ordea, Mitxelenak bere paradigma kritikoa zehaztu duela dirudi eta oreka handiz uztartzen ditu argumentua, gaia, gogoeta nahiz ebaluazioa ere.

Paradigma kritiko horretan, preseski, zuzendaritzaren atalaren balorazioak funtsezko tokia du. Mitxelenak, normalean, ez du alde teknikoaz iruzkinik egiten eta zuzendariaren lana aztertu ohi du. Hala, Cahiers du Cinéma frantziar aldizkariko 
kritikariek aldarrikatzen duten egile zinemaren teoriak bere jardunean eraginik ez duen arren -50eko hamarraldiaren amaieran nazioarteko zinemaren panorama irauli zuten Nouvelle Vague mugimenduko pelikulen falta esanguratsua da-, bere iritzi testuetan argiro nabari da zuzendariari eskaintzen dion berealdiko garrantzia. Horren erakusle da Chaplin, Kazan, Hitchcock, Fellini, Dmytrik, Kramer edo Bergman bezalako zinema zuzendariei Mitxelenak berak aitortzen dien egile izaera.

Interpretazioa da euskaltzainak gehien nabarmentzen duen beste eremuetako bat. Bere kritiketan, bitxia gerta daitekeen arren, ez dio aktoreen lanaren epaiari leku askorik ematen. Zuzen eta labur jorratzen du interpretazioaren atala. Nekez erabiltzen du-eta bizpahiru lerro baino gehiago aktorearen dohainak iruzkintzeko. Le notti di $\mathrm{Ca}$ biria (Federico Fellini, 1957) pelikularen kritikan Giuletta Masina apartari eskaintzen dion azken paragrafoa da salbuespen bakanetako bat. Osterantzean, bere testuetan kasik ez ditu eszenaratzea eta erritmo narratiboa lantzen. Gidoiari buruzko errankizunak, aldiz, argumentuaren inguruko gogoetan inplizituki ageri dira normalean.

Alta, Mitxelenaren estiloa bereizgarri egiten duen zerbait baldin badago, hori, ezbairik gabe, bere idazkera da. Ez alferrik, Elixabete Perez Gazteluk (2015) adierazi legez, zinema kritikak euskaraz idazteko lehengaia -diskurtsoa, lexikoa, esapideak...- moldatu behar izan zuen-eta euskaltzain errenteriarrak. Hain justu, Perez Gazteluk berak apailatutako Mitxelenaren zinema kritiketako hitz elkartuen eta eratorrien bilduma sailkatuak (Perez Gaztelu, 1994; Perez Gaztelu eta Telletxea, 1994) dira haren idazkera oparoaren erakusgarri.

Idazkeraz gain, bere zinema kritika gehienei darien ironia da Mitxelenaren estiloaren beste ezaugarri nagusia. Izan ere, Joxean Fernandezek (2013: 692) dioen moduan, Mitxelenak ironia darabil usu gustuko ez dituen pelikulei buruzko gutxiespeniruzkinak ekiditeko edo Jose Berruezoren -Mitxelenak berak (2006: 17) El Diario Vasco kazetako sasoiko zinema kritikoari eskaini zizkion kritika ziztatzaileak aitortzen ditu- aurkako eztenkadak leuntzeko. Ironiaren erabilera, ordea, ez da horretara bakar-bakarrik mugatzen. Mitxelenak gogoko dituen filmetan ere presente dago.

Agurtzane Azpeitiak (2010: 45-46) -Mitxelenaren enuntziatu parentetikoen ironia sakon eta zehatz analizatu duen ikerlaria- ere uste du hizkuntzalariak ironia erabiltzen duela kritika ziztatzaile eta umoretsu bat egin eta esplizituki inor ez mintzeko. Azpeitiaren iritziz, baina, ironia horren helburu nagusia irakurlearekin konplizitatezko harremana erdiestea da. Alegia, ironiak ezkutatutako esanahiaz jabetzean plazera sentitzen du irakurleak. Eta, ondorioz, konplizitatezko erlazio bat sortzen da euren artean.

Azpeitiaren ikerketaren ondorioak, enuntziatu parentetikoen ironiaren izaera soil-soilik jorratzen badute ere, euskal hizkuntzalariaren zinema kritiken testu gorputz osorako baliozkoak - ñabardurak ñabardura- izan daitezke. Mitxelenak, hortaz, ironia asmo bikoitz batekin darabil zinema idazkietan. Alde batetik, minik egin gabe kritika egiteko. Eta, bestetik, idazle edo kazetari orok irakurlearekin bilatzen duen konplizitatezko harremana kausitzeko.

\subsection{Gostin, egile zinema eta kritika modernoa}

Euskarazko zinema kritikak 70 eta 80ko hamarraldietan barna ere aldizkarietan hartu zuen aterpe. Zeruko Argia aldizkariak eta bere oinordeko Argia-k -1980an aldatu 
zuen izena-, kasu, Donostiako Zinemaldiaren nondik norakoak luze eta zabal jorratu zituzten aipatu hamarraldietan (2008: 274). Nabarmentzeko modukoa da, baiki, Zeruko Argia aldizkariak 1977tik aurrera zinemari eskaini zion garrantzia. Bertan, Joseba Sarrionandia idazleak hamaika zinema kritika idatzi zituen. Iurretarrak, Donostiako Zinemaldiko pelikulak ez ezik, sasoi hartan euskal zinema aretoetan ikusgai zeudenak ere izan zituen gogoetagai. Eta, hein handi batean, euskal zinema kritikaren barnean bide berriak urratu zituen. Izan ere, egile zinemaren ikuspegitik, Oshima, Bertolucci, Fellini, Costa Gavras, Bergman, Allen eta beste hainbat zinemagile handiren obrak ere iruzkindu eta epaitu zituen.

Joseba Sarrionandiaren lekukoa Koldo San Julianek hartu zuen eta zinema kritikaren lanari jarraipena eman zion Argia aldizkarian -Xabier Portugal eta Xabier Etxaniz ere zeregin berean aritu ziren- 80ko hamarraldiaren lehen urteetan. Egile zinemaren aldeko hautua finkatu zen garai honetan, zinez. Ondoren, 1983. urte hasieratik, zinemari eskainitako tartea murriztu zen eta asteroko zinema zutabetxora mugatu zen kasik. Edonola ere, euskarazko zinema kritikak ez zuen bere goieneko maila lortu 1990ean Euskaldunon Egunkaria kazeta sortu zen arte.

Euskal kazetak zinemaz aritu ziren eskarmentu handiko hainbat aditu izan zituen arren, Andres Gostin izan zen, zalantzarik gabe, guztietan esanguratsuena. Itzal handiko zinema kritikari bihurturik, 90eko hamarraldian argitaratutako kritika gehienak sinatu zituen. Juan Jose Iribar ordezkatu zuen Gostinek eta, aurreko belaunaldiak hasitako modernizazioa abiapuntu harturik, molde berria eman zion euskarazko zinema kritikari.

Gostinen zinema kritiketan, Mitxelenarenetan ez bezala, Cahiers du Cinéma frantziar aldizkaritik bultzatutako politique des auteurs delakoaren eragina sumatzen da; ez François Truffaut-ek (2003: 30) teorizatutako moduan, Olivier Assayasek (2003: 154) egiten duen irakurketan baizik.

Beraz, ezin ondoriozta daiteke Gostinek modu itzulezinean uztartzen dituenik zinemagile batekiko atxikimendua eta haren unibertso formalaren ulermena, baina oso agerikoa da zuzendaria -eskaintzen dion pribilegiozko posizioa kontuan hartuta- pelikularen arduradun jotzen duela. Berarentzat, Assayasentzat bezalaxe, filma zinemagilearena da azken honek bakar-bakarrik kontrolatzen dituelako zinema izendatutako artea osatzen duten elementuen berezitasunak.

Egitura mailan ere ageri dira Mitxelenarekiko ezberdintasunak, fitxa teknikoa eta titulua daramatzate-eta Gostinen kritika guztiek. Hala, iritzi testuaren aurretik, filmaren izenburua, aipatu fitxa teknikoa -zuzendaritza, interpretazioa, gidoia, argazkia, musika, ekoizpenaren nazionalitatea eta iraupena ere zehazten dituena- eta argazki oin bat dakarren filmaren irudi bat ere izaten dute.

Halaber, Euskaldunon Egunkaria kazetako kritikariak berebiziko garrantzia eskaintzen dio idazpuruari. Atal honetan, azpitituluari muzin egin eta titulu labur, esanguratsu eta askotarikoen aldeko hautua egiten du. Zenbaitetan, titulu horiek deskribatzaileak dira eta analizatutako pelikularen gaia laburbiltzen dute. Baina, eskuarki, balorazio izaera argia dute eta egilearen epaia islatzen dute. The English Patient (Anthony Minghella, 1996) pelikularen kritikaren tituluaren kasua da: Puzzle erromantiko ederra.

Gostinen testu gehienetan zinema hizkuntzaren alorrik funtsezkoenak sakon disekzionatzen dira, eta horretan datza, hain justu, bere paradigma kritikoaren bertute 
nagusia. Horrenbestez, aztertutako lagina kontuan harturik, gidoiaren analisiak lehentasunezko tokia du bere jarduera kritikoan. Antonio Costak (1988: 201) adierazi legez, gidoiari ez baitzaio kalitate espresibo edo dramatikoa exijitzen soil-soilik. Horrezaz gain, kalitate horrek filmaren ezaugarri estetikoen nahiz ekoizpenean parte hartzen dutenen zerbitzura ere egon behar du.

Gidoia -esplizituki ala inplizituki- oso presente dago Gostinen zinema kritiketan. Are gehiago, obra zinematografikoaren muina da. Zinema kritikariaren diagnosia, ordea, ez da argumentua eta elkarrizketak balioztatzera mugatzen inolaz, gidoiaren egitura zein kohesioari ere garrantzi handia eskaintzen die eta. Izan ere, loturarik gabeko sekuentziak direla gidoiaren beraren sendotasuna apurtzen dutenak uste du usu kritikariak. Beste batzuetan, aldiz, irudimenik ezak -egitura eta gai klasikoen berregite etengabea- argumentuari neurria hartzeko ezintasunak -ibilbide laburreko kontakizunak luzatzea, kasu- edo pertsonaien diseinu ezin txarragoak -pertsonaia lauak, gutxi landuak eta estereotipatuak- zapuzten dute gidoia. Gostinen iritziz, gidoi biribil bat -halakotzat dauka L.A. Confidential (Curtis Hanson, 1997) filmarena-, irudimentsua eta ondo idatzia izateaz gain, argumentu aldetik orekatua eta egoki egituratua dena da. Eta, noski, pertsonaia diseinu apart bat ere baduena.

Eszenaratzea, gidoia irudietan islatzen duen prozesua, Gostinen zinema analisiaren beste oinarrietako bat da. Ramon Carmonaren (1991: 117) arabera, enkoadraketan ageri diren elementuen forma eta konposizioa deskribatzen ditu eszenaratzeak. Zentzu horretan, arte zinematografikoak berezkoak dituen ezaugarriak -kamera mugimenduak, planoen eskala eta tamaina...- eta antzerkiarekin partekatutako beste batzuk ere -argiztapena, jantziak, dekoratuak, esaterako- barnebiltzen ditu.

Eremu honetan, aipatu ezaugarriak lantzen baditu ere, ez du teknizismorik erabiltzen kasik Gostinek. Bere analisi formalak, hein handi batean, orokorrak izan ohi dira eta ezaugarri teknikoak ditu hizpide ezinbestekotzat dituenean soil-soilik. Orobat, egile zinemaren politikarekin bat eginez, eszenaratzearen ardura zuzendariari berari dagokiola uste du.

Normalean, pelikularen kalitatea balioztatze aldera, gidoiaren eta eszenaratzearen artean elkarrekikotasunik ote dagoen analizatu ohi du Euskaldunon Egunkaria kazetako zinema kritikariak. Bestela esanda, idazketaren eta errealizazioaren artean orekarik al dagoen haztatzen du. Gostinentzat, Santos Zunzuneguirentzat (1994: 72) bezalaxe, edukiaren mailan islatzen ez den erabaki espresiborik ez baitago, eta alderantziz. Horren erakusgarri da Career Girls (Mike Leigh, 1997) filmari buruz eskaintzen duen interpretazioa. Aipatu pelikulan, kamera bizkarrean duela errodatzen ditu Mike Leigh zinemagileak protagonisten iraganeko sekuentziarik gehienak. Zinema kritikariaren iritziz, baina, ez da aukera formal hutsa inondik ere; izan ere, mugimendu etengabean dauden irudi dardarti horien bitartez, protagonistek gaztaroan bizi izan zuten orekarik eza helarazi nahi die ikusleei zuzendariak. Egun irudikatzen duten lasaitasun emozionala, aitzitik, plano finkoen bidez islatzen du .

Edozelan ere, ez da oso ohikoa Gostin eszenaratzearen inguruko auziei buruz hain esplizitua izatea. Arestian esan bezala, atal honen inguruan egiten dituen gogoetak izaera orokorrekoak dira eta behar-beharrezkoa dela irizten dionean bakarrik heltzen dio gaiari. Hain zuzen ere, zenbait pelikulatan kamera mugimenduei, planoei, kamera geldoari, eremu-sakonerari eta abarri ematen zaien erabilera azaldu edo 
baloratzeko nagusiki. Halaber, eszenaratze erretorikoekin ere oso kritikoa izan ohi da. Bereziki, itxurakeria formal hantusteak epaitzeko sasoian.

Erritmo narratiboa eta interpretazioa dira Gostinen zinema kritiketan aurki daitezkeen zinema hizkuntzaren beste eremuak. Lehenari dagokionez, zinemagilea da -beste behin ere- filmari erritmo narratibo egokia emateko ardura duena. Berak baitu pelikula osatzen duten plano, eszena eta sekuentzien iraupenari buruzko azken hitza. Dena dela, erritmo narratiboaren analisia Gostinen arreta gune esanguratsuenetakoa bada ere, eskaintzen dituen azalpenetan ez da normalean xehetasunetan sartzen. Atal horren inguruko balorazio orokorrak egiten ditu, jarraitutasun narratiboari eragiten dioten arazoetan enfasi berezia ipiniz. Era berean, modu oso puntualean izan arren, erritmo narratiboarekin zerikusirik duten beste arazo batzuk ere ditu hausnarketagai: gehiegizko iraupena, loturarik gabeko eszenak, artifizio formalak, eta narrazio-jario arina lastatzen duten beste hamaika eragozpen.

Interpretazioaren eremuak, bestalde, ezinbesteko garrantzia du Gostinen jarduera kritikoan. Halaz ere, bere zinema kritika ia guztietan ageri den arren, ez dio tarte handirik eskaintzen. Azken paragrafoan kokatutako lerro bakan batzuk baino ez. Antza, zinema kritikariak jarduera interpretatiboa obra zinematografiko osoaren adierazpen gisa ulertzen duela dirudi. Horregatik, kasurik gehientsuenetan, pelikularen beste alderdiekin loturik dago interpretazioa eta ez da haren kalitatearen isla argia besterik. Gutxi batzuetan, aldiz, maila interpretatiboa da aipagarriena dena.

Alor honetako balorazioak ere orokorrak dira maiz eta aktoreak pertsonaiaren ezaugarrietara moldatu eta erregistroz aldatzeko duen gaitasuna laudatu ohi dute. Hoztasunak, histrionismoak eta larjotzeak, ostera, gaitzespena eragiten dute. Orobat, esanguratsua da kritikariak behin baino gehiagotan bigarren mailako aktoreen lana protagonistenaren gain nabarmendu izana. Hortaz, analisiak aipatu izaera orokorra duenez gero, oso gutxitan eskaintzen da aktorearen aurpegiaren emozioak biluzten dituen interpretazio lanaren berariazko tratamendurik. Secretos del corazón (Montxo Armendariz, 1997) filmeko Andoni Erbururen begirada xaloaren irakurketa da, zalantzarik gabe, salbuespen bakar horietariko bat.

Gostinen jarduera kritikoa, ordea, ez da ikertutako zinema hizkuntzaren eremuetara mugatzen. Bere testuek, irakurleari obraren balorazio estetiko bat eskaintzeaz gainera, giza izaerari buruzko hausnarketa argi eta oparoa dakarte ere sarri-askotan. Gauzak horrela, iruzkindutako filmen interpretaziotik eratorritako gai kultural, sozial zein antropologikoak gogoeta sakonaren xede bihurtzen dira. Eta, gogoeta hori, egileak berak darabiltzan zinema zein literatur aipamen anitzekin aberasten da.

\subsection{Gontzal Agote eta testuinguru digitalaren erronka berriak}

Egun tokiko euskarazko hainbat aldizkari eta kazetatan zinema kritika lantzen den arren, Berria -Euskaldunon Egunkaria kazetaren itxieraren ostean haren lekukoa hartu zuen argitalpena- bilakatu da 2003az geroztik eredu nagusi alor honetan. Hastapenetan, Alberto Irazu izan zen nolabaiteko jarraitutasuna mantendu zuen egunkariko zinema kritikari bakarra. Dena dela, sasoi horretan bertan, denbora tarte batez jarduera berbera partekatu zuten beste zenbait kritikari ere izan ziren. Gontzal Agote, hain zuzen ere, 2005ean hasi zen zinema kritikak argitaratzen. Urte hartan bertan, Donostiako Zinemaldiko sail ofizialean parte hartu zuten filmen kritikak idazteko 
ardura izan zuen-eta estreinakoz. Halarik ere, ez zen Berria kazetako zinema kritikari nagusi gisa finkatu hiru urte geroago arte. Harrez geroztik, egunkariaren zinema irizpidea markatzen du.

Agoteren paradigma kritikoak antzekotasun handiak ditu Gostinenarekin. Bere kritiketan, egile zinemaren itzala luzea da eta edukian forman baino areago sakontzen da. Bi ereduen artean, ostera, ezberdintasun esanguratsuak ere izan badira; gehienak, testuinguru berriak sorraraziak. Izan ere, Agote Berria egunkarian kritikari gisa finkatu zen sasoian 2008ko krisi ekonomikoak prentsak teknologia iraultzaren eraginez pairatzen zuen egoera gordina larriagotu zuen.

Hala, sareko euskarazko zinema kritiken areagotzeak Agoteren kritikari autoritateari ia kalterik egin ez dion arren -neurri handi batean, eragin ahalmen urria dutelako-, krisi ekonomikoaren ondorioek, baina, ikaragarri baldintzatu dute bere jarduera. Zinema kritiken argitaratze maiztasuna eta kazetak berak bere orrialdeetan eskaintzen dien espazioa kontuan hartuta, bederen.

Bere zinema kritikak aztertuz gero, egitura aldetik Gostinen zinema kritikekin antz handia dute. Hortaz, titulu eta fitxa tekniko bana izaten dute. Tituluak, laburrak ez ezik, deskribatzaileak dira nagusiki. Edonola ere, haietako askok egilearen epaia aurreratzen dute. Fitxa teknikoak, bere aldetik, aldaera batzuk aurkezten ditu. Gehienetan horiz koloratutako kaxa batek bereizi ohi du testuaren gorputzetik eta, filmaren titulua argitzeaz gain, zuzendaritza, interpretazioa, nazionalitatea eta ekoizpenaren iraupenaren berri ere ematen du. Berritasunik aipagarriena, ezbairik gabe, kritikariak pelikulari eskainitako puntuazioa - batetik bostera doan eskala erabilita- da.

Edozelan ere, ezberdintasunik agerikoena, zinema kritikaren testuaren gorputzaren luzeran ematen da. Kazetaritzak nozitzen duen krisi bikoitzaren eraginez -kazetaritzarena berarena eta azken urteotan bizi dugun krisi ekonomiko latza-, mundu osoko kazeta gehienek zinema kritikari eskainitako tartea ikaragarri murriztu dute. Eta, zentzu horretan, Berria egunkariaren kasua ez da, noski, salbuespen. Hala, 90eko hamarraldian Gostinen zinema kritikek, batez beste, 400 hitz inguruko luzera zuten eta Agoterenak, berriz, nekez iristen dira 250 hitzetara. Hori aski ez dela, zinema kritikak ez dakar beti analizatutako filmaren argazkiren bat berarekin. Zenbaitetan, Kultura saileko beste gaiei tarte gehiago eskaintzeko asmoz, argazkirik ez da argitaratzen.

Zinema kritikari eskainitako tartea ia erdira murrizteak ondorio zuzena du azken emaitzan. Izan ere, murrizketa horrek zinema kritikariaren berezko funtzioei eragiten die eta iritziak ñabartzea, argudioak lantzea edo gauzak euren testuinguruan jartzea izugarri zailtzen du (Planes Pedreño, 2014: 110).

Baldintza horien pean bada ere, Agoteren zinema kritikek, hein handi batean behintzat, Gostinen paradigma kritikoak utzitako uharari jarraitzen diote. Ez alferrik, Cahiers du Cinéma aldizkariaren goieneko unean kritika argitzaileak sustatutako egiletzaren ideia oso presente dago bere testuetan. Ondorioz, esanahiaren iturri sortzailetzat jotzen du zuzendaria Agotek. Bordwellek (1995: 62) dioen bezala, zuzendari baten ekoizpena obra bat balitz bezala hartzen baitu, berezko gai eta estilo-aukera jakin batzuen errepikatze eta birsortze modura. Joera hori argi eta garbi islatzen da Saul fia (2015), Cafe Society (2016), Nocturama (2016) eta Dangsinjasingwa dangsinui geot (2016) filmen kritiketan. Pelikula horiek guztiak, hurrenez hurren, 
Laszlo Nemes, Woody Allen, Bertrand Bonello eta Hong Sang-soo-ren obraren parte gisa analizatzen ditu-eta Agotek.

Kritika argitzailearen arabera, kritikaren jardueraren xede nagusia pelikulei esanahi inplizituak ematea da (Bordwell, 1995: 61). Hori dela eta, ulergarria da Berria kazetako kritikariak obren mezu eta gaiei izaera formalari baino tarte handiagoa eskaintzea. Zentzu horretan, Agoteren kritiketan nagusi den zinema hizkuntzaren eremua gidoiarena da. Hortaz, beste eremuek, eszenaratzeak eta erritmo narratiboak beregainki, bigarren mailako rola dute.

Era berean, agerikoa da oso zinema kritikari eskainitako tarte txikiak zinema kritikariaren jardueran eraginik duela. Testuinguru berri horretan, ezinezkoa zaio kritikariari zinema hizkuntzaren eremu guztietan maila berean sakontzea eta aukeratu behar du. Nolanahi ere, aukera horren arrazoiak ere oso bestelakoak izan daitezke. Bere kritikari jardueran irakurlearekiko komunikazioa lehenesten duela aitortzen du Agotek. Horrek teknizismo eta digresio formalak alboratzeko duen joera azalduko luke, apika.

\begin{abstract}
"Zenbaitetan, zinema kritikaren gaitzetako bat geure buruarentzat bakarrik idaztea da, dakigunaz harro azaltzeko, arrastoak -ez zinema irakaspen batnahi dituen jendearentzat idazten dugula ahantziz. Ikuspegi hori ez galtzea garrantzitsua da oso, hedabide jeneralistetan bereziki. Ez dadila exhibizionismo saio bat izan. Irakurtzen edo entzuten duen jendearekin nolabaiteko enpatia bat erdietsi behar du zinema kritikariak, irizpide bat osatzen lagun diezaion" (Joxean Fernandez, 2015: 300).
\end{abstract}

Azken batez, Agoteren paradigma kritikoak, egile zinemaren politikarekin leial eta naroa oso zinema aipamenetan, lehentasuna ematen dio edukiaren mailari. Bere gogoeta kritikoa, bereziki, obra zinematografikoen esanahi esplizitu edo inplizituetatik eratortzen diren gai zein mezuetan ardazten da. Horrenbestez, ezinbestekoa denean soil-soilik sartzen da maila formalean. Finean, irakurlearen zerbitzura dagoen iritzi testu gogoetatsua da zinema kritika Agoterentzat. Kontatu eta baloratu ez ezik, irakurlea gidatzen duena. Eta, aldi berean, bere irizpidea osa dezan beharrezkoak zaizkion zumeak dakarzkiona.

\title{
4. Ondorioak eta eztabaida
}

Bilakaera luze eta sakon baten emaitza da euskarazko zinema kritika garaikidea, bada. Hastapenetan, Mitxelenaren idazkietan, filmen edukiek kritikariari iradokitako gogoeta antropologikoak dira nagusi. Horrez gainera, aipamen gehienak, zinemaren esparrukoak baino, literatur eremukoak dira. Halaber, eszenaratzearen islarik ez dago. Alde formalak lekurik ez du-eta kasik zinema kritikarik goiztiarrenetan.

XX. mende amaierako zinema kritiketan, ostera, errotikako aldaketak jazoko dira. Egiturari dagokionez, fitxa teknikoa eta titulua -adierazkorra, nagusiki- dakartzate jada Andres Gostinek Euskaldunon Egunkaria kazetan argitaratutako zinema kritika guztiek. Edukiaren esparruan, berriz, Cahiers du Cinéma aldizkariak sustatutako 
eredua gailentzen da. Egile zinemaren espiritua, alegia. Eta, ondorioz, aipamen gehienen sustraiak zinematografikoak dira. Era berean, eszenaratzeak berebiziko garrantzia erdiesten du. Forma eta edukia elkarren osagarri bihurtzen baitira.

Ezpal berekoa da Gontzal Agotek Berria egunkarian egun lantzen duen zinema kritika. Egile zinemaren eraginak bere horretan dirau, eta zinema aipamenei lotuago dago kritikaria. Laburragoa da zinema kritika, baina. Edukian forman baino ardaztuagoa. Horrenbestez, ñabardurak ñabardura, europar prentsan argitaratzen den zinema kritikaren ezaugarriak bere egiten dituela esan genezake.

Nolanahi ere, prentsan argitaratutako euskarazko zinema kritikak egungo testuinguru digitalak dakartzan erronka berriak aintzat hartu beharko ditu bizirauteko eta bere jite erreferentziala mantentzeko ere. Sasoi berri honetan, pantaila berriak -sakelako telefonoa, ordenagailua, Ipad-a- sortu dira eta Internet sareak merkataritzako industriak hamarraldi luzez ezarritako muga geografikoak apurtu ditu. Beraz, zinemaren mapa aldakorraren aurrean erne egon behar du zinema kritikariak. Fenomeno honen inguruan dituen pertzepzio eta azalpenek mutazio ezberdinen erritmoa jarraitu behar baitute (Pere Portabella, 2010: 8).

Etengabe aldatzen ari den zinema horrekin batera aldatu behar du ere zinema kritikariak desagertu edo gelditasunik antzuenean zendu nahi ez badu. Sareari esker, sasoi batean ezezagunak zitzaizkion eta bere ikuspegia alda dezaketen munduko hamaika zinematografia ezagut ditzake egun. Testuinguru horretan, kazetako zinema kritikak alor digitalera zabaldu behar du bere egitekoa berehalaxe. Zabaldu ez ezik, garatu ere. Alde batetik, bere autoritate erreferentziala mantentzeko. Eta, bestetik, bere arrazoibidea perfekzionatu eta izaera pedagogikoa areagotzeko.

Paperezko egunkarian astean behin inprimatzen den zinema kritika bertsio digitalean kopiatzearekin ez da aski jada. Zinea.eus edo Zinemauneak.eus gisako weborrialdeek zerbitzu berbera ematen dute eta zinemaren inguruko euskarazko blogak -Gaizka Izagirrerena, kasurako- gero eta landuagoak dira eta zinemaren panorama garaikidea hobe islatzen dute.

Euskarazko zinema kritikak, ekarpenik berritzaileenak aintzat hartu arren, berezi egiten duten hainbat ezaugarri mantentzen du. Gogoetaren aldeko jarrera eta edukiaren eremuranzko joera, batik bat. Halaber, nabarmentzeko modukoak dira ere irakurlearekiko agertzen duen enpatia eta bere orientazio pedagogikoa. Ezaugarri horiei guztiei ez die uko egin behar inolaz, berezkoak dituelako. Edozelan ere, arestian adierazi legez, ezinbestekoa du testuinguru digital berriaren erronkak bere egitea. Horrenbestez, euskarazko zinema kritikak ingurune digital berrira egokitu behar du bere idiosinkrasia alboratu gabe eta, ahal duen neurrian, bere alde adierazkorra ere areagotuz. Finean, bere burua eraberritu behar du funtsa galdu gabe. 


\section{Erreferentzia bibliografikoak}

Aumont J, Marie M. (1993). Análisis del film, 2.ed. Bartzelona: Paidos.

Azpeitia A. (2010). Enuntziatu parentetikoak: Koldo Mitxelenaren intentzio ironikoaren ispilu. Gogoa, 10 (1\&2), 21-54.

Baecque A (konp.) (2003). La política de los autores. Manifiestos de una generación de cinéfilos, 1.ed. Bartzelona: Paidos.

Basallo A. (2016). Julián Marías, crítico de cine. El filósofo enamorado de Greta Garbo, 1.ed. Madril: Forcola.

Bordwell D. (1995). El significado del filme. Inferencia y retórica en la interpretación cinematográfica, 1.ed. Bartzelona: Paidos.

Carmona R. (1991). Cómo se comenta un texto fílmico, 1.ed. Madril: Catedra.

Costa A. (1998). Saber ver el cine, 1.ed. Bartzelona: Paidos.

Fernandez J. (2013). Koldo Mitxelena, crítico de cine en euskera durante el franquismo. Koldo Mitxelena Katedraren III. Biltzarra: Gasteiz, 2012/X/8-11: EHUko Letren Fakultateko areto nagusia, (743-755).

Fernandez J (ed.). (2015). Cine vasco: tres generaciones de cineastas, 1.ed. Donostia: Euskadiko Filmategia.

Lertxundi, A. (1987). Egarri literarioak. Egan, XL, 3-6 z., 93-98.

Mitxelena, K. (1981). Denbora bateko zinema paperak 1954-1961. Bilbo [2006, Mujika Iraola, I. (ed.)].

Perez Gaztelu, E. (1994). Koldo Mitxelenaren zinema-kritiketako hitz elkartuak. Euskaltzaindia, liburukia 39-3, 1110-1128.

Perez Gaztelu, E. (2015). Koldo Mitxelena: XX. mendeko gogogiroa euskaraz. Edo euskal kultura zabaldu eta berritu beharra. Euskonews, 703. Hemen berreskuratua: http://www.euskonews.com/0703zbk/gaia70301eu.html.

Perez Gaztelu, E. eta Telletxea, M. (1994). Koldo Mitxelenaren zinema-kritiketako hitz eratorriak. Euskaltzaindia, liburukia 39-3, 1129-1157.

Planes Pedreño J A. (2014). El paradigma estético en la crítica cinematográfica de Ángel Fernández-Santos. Tesia. Gizarte eta Komunikazio Zientzien Fakultatea. UCAM Universidad Católica de Murcia. Murtzia.

Rosenbaum J, Martin A. (2010). Mutaciones del cine contemporáneo, 1.ed. Madril: Errata Naturae.

Torrado S. (2008). El cine vasco en la bibliografía cinematográfica (1968-2007), 1.ed. Donostia: Deustuko Unibertsitatea / Euskadiko Filmategia.

Zumalde I. (2011). La experiencia fílmica. Cine, pensamiento y emoción, 1 .ed. Madril: Catedra.

Zunzunegui S. (1994). Paisajes de la forma. Ejercicios de análisis de la imagen, 1.ed. Madril: Catedra. 